\title{
A comparison on the performance and risk diversification benefits of real estate investment trusts in Malaysia and Singapore
}

\author{
$N g$ Ching Yat David ${ }^{*}$, Leong May Li ${ }^{1}$, Lau Teck Chai ${ }^{2}$, and Fitriya Abdul Rahim² \\ ${ }^{1}$ Department of Accounting, Faculty of Accountancy and Management, Universiti Tunku Abdul Rahman \\ ${ }^{2}$ Department of International Business, Faculty of Accountancy and Management, Universiti Tunku Abdul Rahman
}

\begin{abstract}
This study analyses the investment performance and effectiveness of risk diversification between M-REITs' and S-REITs' by comparing their respective Sharpe Ratio, Treynor Ratio and Jensen's Alpha including the diversification measures (unsystematic risk divided by total risk and one-minus $\mathrm{R}$ squared) calculated on each REITs. The study period for M-REITs' extends from 2007 to 2016 and for S-REITs' from 2002 to 2016. Results shows that M-REITs' perform better than S-REITs' in terms of Sharpe ratio, Treynor ratio, and Jensen's Alpha. Total risk of S-REITs' are higher than M-REITs'. The Beta values for both M-REITs' and S-REITs' are less than one, implying that both categories of REITs are less risky than the market index. M-REITs' have lower R-Squared values than S-REITs', which suggests that M-REITs' are poorly diversified than S-REITs' and therefore, M-REITs' have more diversification opportunities. The diversification measures computed for M-REITs' are higher than S-REITs' and would imply that M-REITs' have better rate of returns if M-REITs' diversify their risk (higher risk diversification benefits). The findings from this study aims to help investors to make better investment decision when investing in M-REITs' and S-REITs'. Top and poor performers of M-REITs' and S-REITs' are determined in this study. The findings from this study aims to assist investors determine better investment decisions when considering investing in M-REITs' and S-REITs'. Keywords: M=REITs, S-REITs', Performance, Risk Diversification.
\end{abstract}

\section{Introduction}

Properties in the sixties were expensive for most people because properties are classified as highly priced assets. Nowadays, Real Estate Investment Trusts (REITs) have become a mainstream of investing in real estate in many countries. Malaysia Real Estate Investment Trusts (M-REITs') and Singapore Real Estate Investment Trusts (S-REITs') have been developed since the 20th century. Significant studies have been conducted in the past to provide a thorough understanding on the important contribution of REITs to broader equity market in order to provide valuable information and guideline to investors and other stakeholders.

The purpose of this research is to investigate and compare the investment performance and risk diversification features of M-REITs' and S-REITs' using the classical but well-known standard performance measurement methods, namely Sharpe Ratio, Treynor Ratio and Jensen Alpha.

The hypotheses examined for this study are as follows:

Hypothesis 1

To examine the Beta value for both of each M-REITs' and S-REITs':

$H_{o}:$ 9M-REITs" $\beta>$ S-REITs" $\beta$ (M-REITs' have higher Beta [market risk] compared to S-REITs')

$H_{1}$ : M-REITs" $\beta<$ S-REITs" $\beta$ (M-REITs' have lower Beta [market risk] compared to S-REITs')

Hypothesis 2

To examine the performance measurement between M-REITs' and S-REITs' index using Sharpe ratio:

$H_{o}$ : M-REITs" Si < S-REITs" Si (M-REITs' have lower Sharpe ratio compared to S-REITs')

$H_{1}$ : M-REITs" Si > S-REITs" Si (M-REITs' have higher Sharpe ratio compared to S-REITs')

Hypothesis 3

To examine the performance measurement between M-REITs' and S-REITs' index based on Treynor Ratio:

$H_{o}:$ M-REITs" Ti < S-REITs" Ti (M-REITs' have lower Treynor ratio compared to S-REITs')

Corresponding author: Ng Ching Yat David (ngcy@utar.edu.my) 


\section{$H_{1}:$ M-REITs" Ti > S-REITs" Ti (M-REITs' have higher Treynor ratio compared to S-REITs')}

\section{Hypothesis 4}

To examine performance measurement between M-REITs' and S-REITs' index according to Jensen's Alpha:

$H_{o}:$ M-REITs" $\alpha \mathbf{i}<$ S-REITs" $\alpha i$ (M-REITs' have lower Jensen's Alpha compared to S-REITs')

$H_{1}:$ M-REITs" $\alpha i$ > S-REITs" $\alpha i$ (M-REITs' have higher Jensen's Alpha compared to S-REITs')

Hypothesis 5

To examine risk diversification benefits between M-REITs' and S-REITs':

$H_{o}:$ M-REITs" Rd < S-REITs" Rd (M-REITs' have lower risk diversification benefits compared to S-REITs')

$H_{1}:$ M-REITs" Rd > S-REITs" Rd (M-REITs' have higher risk diversification benefits compared to S-REITs')

This research will examine the performance and risk diversification capabilities of M-REITs' and S-REITs'. The research will provide investors insights into the performance and risk diversification benefits. The research intends to develop on existing literature by analysing and providing evidence on the performance and risk diversification benefits of M-REITs' and S-REITs'.

\section{Literature Review}

Findings by Hamzah, A.H. et al. (2010) showed the extent of systematic risks in M-REITs' during the economic crisis and post-crisis period while determining the degree of return that REITs will offer compared to the market portfolio during that particular period. The research signified that the risk-adjusted performance of M-REITs' varied from time to time. The overall result of the study concluded that the systematic risk of M-REITs' was significantly higher during economic crisis period compared to post-crisis period. Ng, Lim, Lau, and Yuen (2015) had analysed risk-adjusted performance of sixteen listed property trust in Malaysia from year 2007 to 2015 using the three main standard performance measurement tools: Sharpe Ratio, Treynor Ratio and Jensen's Alpha to estimate risks, returns and riskadjusted performance of the respective M-REITs'. They suggested that investors who invested in M-REITs' will provide a preferable return because all the M-REITs' outperform the market benchmark during that particular period of time. This was consistent with Smith \& Shulman (1976) findings that REITs tend to provide a higher return than the market index and saving accounts.

Low. S.W. and Anwar Johari (2014) examined the degree of performance and risk diversification of twelve M-REITs' over 2007-2012. Similsr to Hamzah, A.H. et al. (2010) and Ng, D.C.Y (2015), they also utilized Sharpe Ratio, Treynor Ratio and Jensen's Alpha as the REITs' performance evaluation methods. They also employed an additional performance evaluation approach called M-squared measure as an extra evaluation method. Based on Low. S.W. et al. (2014), the M-squared measure was developed by Markowitz's (1952) portfolio theory which emphasized the concept of accomplishing a desirable fund performance for any risk level by utilizing leverage as an evaluation tool. The results from the study provided an optimal impression to investors by assisting them in their investments into REITs.

In the Singapore context, Liow (2001) conducted a study to investigate the risk-adjusted investment performance of S-REITs' and its property stocks over the past 25 years. The study employed Sharpe Index and Jensen-Varying Abnormal Return Index to examine the risk-adjusted performance and portfolio return of all the S-REITs' from 19751999. The outcome of the study implied that the S-REITs' outperform against the market portfolio with the higher returns and lower risk levels. Another study investigated the overall risk-adjusted performance on Singapore financial vehicles from 1975-1995 such as stock market, property stocks, residential, commercial, and industrial properties (Liow 1997a). The results of the study concluded that there was a significant difference between the excess return generated from owning direct properties and the excess return generated from owning property stocks such as REITs. Peng Liu (2010) identified certain corporate finance issues involving REITs. Capital structure, corporate governance, dividend pay-out policy, and initial public offerings are the main issues involving REITs. The study also explored several regulatory constraints or requirement required to develop a REIT such as distribution requirements, asset requirements, income requirements, and ownership requirements. Hartzell, Sun, and Titman (2006) examined how the corporate governance of a firm affects the REITs investment decisions. The study found that the investment performance of REITs was really dependent on how well the REIT conducts its corporate governance. REITs that adhered to corporate governance lead to positive real estate investment opportunities.

The present study contributes to and extends the evaluation on the risk adjusted performance of S-REIT by employing the same performance measurement method as it is applied to M-REIT, and compare the results between the MREITs and S-REITs with the classical measurement tools of Jensen's Alpha (1968), Sharpe (1966) and Treynor (1965). 


\section{DATA AND METHODOLOGY}

The sampling data consist of 16 M-REITs' for the period from 2007 to 2016 and 26 S-REITs' for the period from 2002 to 2016.

return of the investment will changed in a steady pace. The calculation for standard deviation is shown below:

For this research, stock prices of the 16 M-REITs' and 26 S-REITs' listed were collected from Bloomberg financial software and are leveraged to represent the value used as a comparison against the indexes from FBM Kuala Lumpur Property and FTSE ST REIT. Specifically, the 10 years' weekly returns of M-REITs' and FBM Kuala Lumpur Property Index are used to measure all of the selected variables. 15 years' of S-REITs' weekly returns and FTSE ST REIT Index were used to calculate each of the variables selected for Singapore.

The weekly returns of the $16 \mathrm{M}$-REITs' and 26 S-REITs' are calculated using the following formulas:

whereby,

$$
\mathrm{Rt}=\frac{P_{t}-P_{t-1}}{P_{t-1}} \times 100
$$

$\mathrm{Rt}=\mathrm{M}$-REIT stock price for week $\mathrm{t}$

$\mathrm{Pt}=$ Closing share price of M-REIT at the chosen day of week $\mathrm{t}$

Pt-1 = Closing share price of M-REIT at the chosen day of week before week $\mathrm{t}$

The weekly returns for FBM Kuala Lumpur Property Index and FTSE ST REITs Index were calculated as follows:

whereby,

$$
\text { Rindex }=\frac{I_{t}-I_{t-1}}{I_{t-1}} \times 100
$$

Rindex $=$ Index for week $\mathrm{t}$

It $=$ Closing index value at the chosen day of week $t$

It-1 = Closing index value at the chosen day of week before week $t$

The standard deviation of each REIT was computed and subsequently, interpreted to determine the volatility each of the REIT against the respective property index (ie FBM Kuala Lumpur Property or FTSE ST REIT). Standard deviation of REITs is a statistical measure of the volatility of the sample weekly return for each REIT. An investment portfolio that has a lower standard of deviation as compared to its benchmark value, may seem preferable for risk averse investors. This is because the lower the value of standard deviation, the lower the risk or uncertainty within the portfolio (for example, the return of the portfolio does not change dramatically over a period of time). An investor who prefer investments with a low standard deviation, the implications will be that the potential

$$
\sigma=\sqrt{\frac{\sum_{i=1}^{n}\left(X_{i}-\mu\right)^{2}}{n-1}}
$$

Whereby:

$\mathrm{Xi}=$ weekly return of REITs

$\mu=$ the mean return of REITs for the year (\%)

$\mathrm{n}=$ sample period (years)

Apart from the above, the total risk were computed, which include systematic risk, unsystematic risk and diversification measure, and compared among the 26 S-REITs' and 16 M-REITs'. The formula for calculating the total risk is shown below:

Whereby,

$$
\sigma \mathrm{i} 2=\beta \mathrm{i} 2 . \sigma \mathrm{m} 2+\sigma \mathrm{e} 2
$$

$\sigma \mathrm{i} 2=$ Total risk for REITs

$\beta \mathrm{i} 2$ = Square of Beta of REITs

$\sigma \mathrm{m} 2=$ Variance of return of the market portfolio

$\beta \mathrm{i} 2 \sigma \mathrm{m} 2=$ Systematic risk of REITs

$\sigma \mathrm{e} 2=$ Unsystematic risk of REITs

Two methods were used to calculate the diversification measures of the REITs. Diversification can be defined as a process of allocating capital in order to reduce the exposure to risk. In the investor's' perspective, diversification is a way to reduce volatility by investing in a variety of assets. 
The first method is by dividing the unsystematic risk with total risk. If the ratio is closer to 0 , it implies that the unsystematic risk of the REIT is less significant.

The calculation for diversification measure is shown below:

$$
\text { Diversifiability measure }=\frac{\sigma_{e}^{2}}{\sigma_{i}^{2}}
$$

whereby,

$\sigma_{e}^{2}=$ Unsystematic Risk of REITs

${\sigma_{i}}^{2}=$ Total Risk of REITs

The second method is one minus $\mathrm{R}$-Squared ( $1-\mathrm{R}$-squared). If the diversification value computed is high, this would mean that the diversification opportunities or risk diversification benefits is high. If the value is near to zero, this means that there is less unsystematic risk in the portfolio and more systematic risk, which cannot be diversify. However, if the diversification measure has a value that is near to one, it would mean that the portfolio consists mainly of unsystematic risks which can be diversify.

The calculation of diversification measure is shown below:

$$
\text { Diversifiability measure }=1-\mathrm{R}^{2}
$$

whereby, 
$\mathrm{R}^{2}=\mathrm{R}$-squared

In addition, the R-square of each REIT are also computed to examine the market movement of a security or portfolio that can be predicted by the movement of portfolio benchmark. The R-squared demonstrates the relationship between the total risk and systematic risk, as it explained the degree of total risk being affected by systematic risk. The formula for calculating the R-Squared value of REITs is shown below:

$$
R^{2}=\frac{\beta_{i}{ }^{2} \cdot \sigma_{m}{ }^{2}}{\sigma_{i}{ }^{2}}
$$

whereby,

$R^{2}=\mathrm{R}$-Squared

$\beta_{i}{ }^{2}=$ Square of portfolio's beta

$\sigma \mathrm{m} 2=$ Variance of return of the market portfolio

Bi2 . $\sigma \mathrm{m} 2$ = Systematic risk component of REITs

$\sigma \mathrm{i} 2$ = Total risk

The higher the value of R-Squared, the higher the chances of a security or portfolio moving in the same direction with the market index. A high value R-Squared indicates that the inherent total risk within a REIT is aggressively affected by the systematic risk and vice versa. In contrast, if the R-Squared has a low value, it denotes that the security or portfolio does not move along with the market index. In another words, a portfolio with a low value of R-Squared does not act much like the market index.

Subsequently, the risk-adjusted performance measures of the REITs are computed using the Sharpe Ratio, Treynor Ratio and Jensen's Alpha to ascertain how the REITs are performing against the risk estimated, as well as, identify the possible excess return from each REIT against the market index.

The Sharpe Ratio calculates the excess return earned in the excess of the free rate of return per unit of standard deviation in an investment portfolio. In calculating the Sharpe Ratio, the three main components are free rate of return, average return of the portfolio, and standard deviation or volatility. The standard deviation is used to present the diversity of the returns over a sampling period.

The calculation for Sharpe Ratio is shown below:

$$
S R=\frac{r_{i}-r_{f}}{\sigma_{i}}
$$

whereby,

$\mathrm{SR}=$ Sharpe Ratio

ri = average return of REITs

$\mathrm{rf}=$ risk free rate of return

$\sigma_{i}=$ standard deviation of REITs

The higher the value of Sharpe Ratio denotes that the portfolio generate a greater return against the portfolio benchmark. Likewise, the Sharpe Ratio with a negative value represents that the portfolio generates a lesser return against the risk-free rate of return.

Treynor Ratio is a measurement of the return generated from the investment portfolio on a risk-adjusted basis. The calculation of Treynor Ratio is shown below:

whereby,

$$
T=\frac{r_{i}-r_{f}}{\beta_{i}}
$$

$\mathrm{T}=$ Treynor Ratio

ri = average return of REITs

$\mathrm{rf}=$ risk free rate of return

$\beta \mathrm{i}=$ beta of portfolio

To justify the performance of REITs, a Treynor Ratio with a positive value is always preferable in REIT markets. The higher the Treynor Ratio is, the greater the return generated from portfolio against the portfolio benchmark. A Treynor Ratio with a negative value indicates that the estimate of the performance of a REIT is not so optimistic. Jensen's Alpha is an abnormal return evaluation tool that utilizes the capital asset pricing model (CAPM) to estimate the rate of return on the basis of market volatility by measuring the REITs' beta and compare it with the market beta.The given portfolio's beta denotes the volatility of the REITs at the market as a whole. It also represents the risk which has been arising along the market movement. The formula to compute Jensen's Alpha is shown below:

$$
\alpha_{\mathrm{i}}=\mathrm{R}_{\mathrm{i}}-\left[\mathrm{R}_{\mathrm{f}}+\beta_{\mathrm{i}}\left(\mathrm{R}_{\mathrm{m}}-\mathrm{R}_{\mathrm{f}}\right)\right]
$$

Corresponding author: Ng Ching Yat David (ngcy@utar.edu.my) 
Whereby,

$\alpha_{i}=$ Jensen's Alpha for REIT

$\mathrm{Ri}=$ return of REIT

$\mathrm{Rf}=$ risk free rate

$\beta i$ =beta of portfolio

$\mathrm{Rm}=$ return of portfolio market

\section{EMPIRICAL FINDINGS AND DISCUSSION}

The overall average weekly returns of the 16 M-REIT is approximately $0.1826 \%$ and it outperformed the FBM KL Property Index average weekly return of approximately $0.0623 \%$.

For the 26 S-REITs', the overall average weekly return is approximately $0.0945 \%$ which has generated excess return against the FTSE ST REIT average weekly return of approximately $0.0333 \%$. M-REITs' generated approximately two times more return than S-REITs'. The overall rate of return generated by S-REITs' is lesser than those in M-REITs' because some of the S-REITs' such as AIMS AMP Capital Industrial REIT, Cache Logistics Trust, OUE Com, and Sabana Shariah Compliant REIT underperformed against the FTSE ST REIT. These S-REITs' reported a negative average return at the end of 2016 and this had affected the average return of the overall REITs market in Singapore. For standard deviation, S-REITs' achieved a higher average return volatility of approximately $3.2335 \%$ which exceeded the FTSE ST REIT's average return volatility of approximately $3.1408 \%$. On the other hand, the average return volatility in M-REITs' is approximately $2.1430 \%$.

Table 1 and Table 2 reveals findings on the total risk features of each REIT.

Insert table 1 and table 2

Total market risk of S-REITs' is relatively higher compared to the total market risk of M-REITs'. The average risk value recorded in M-REITS' and S-REITs' are approximately $4.7563 \%$ and $11.5580 \%$ respectively and this signifies that the total risk taken by S-REITs' and M-REITs' are significantly different. The total risk taken by S-REITs' is approximately 2.5 times greater than the total risk taken by M-REITs'. In terms of systematic risk, M-REITs' have relatively lower risk level compared to S-REITs'. The findings showed that the average systematic risk level of all MREITs' is approximately less than $1 \%$, while S-REITs' is approximately $4.4476 \%$. This implies that there is a significant diversifiable risk and uncertainty inherent in most of the S-REITs'. Meanwhile, the average beta generated in the S-REITs' is greater (approximately 0.8195 ) than the average beta value of M-REITs' (approximately 0.1731). This explains that the volatility of S-REITs' against the market movement is relatively higher compared to M-REITs'. Among the 26 S-REITs', 6 of them have beta value of more than 1 which are CapitaLand Commercial Trust (1.12288), CapitaLand Mall Trust (1.32985), Frasers Commercial Trust (1.16653), Fraser Logistics \& Industrial Trust (1.21336), Mapletree Greater China Commercial Trust (1.10479), and Mapletree Commercial Trust (1.04678). Those S-REITs' with high beta value contribute a high level of systematic risk to the S-REITs' market. From the MREITs' perspective, the findings showed that the volatility of each M-REIT is low and contributes a lower level of systematic risk than the market portfolio. In short, it can be speculated that M-REITs' is a defensive investment portfolio which ensures the regular portfolio rebalancing; while S-REITs' is a speculative investment portfolio which presents more risks and uncertainties. Table 1 showed that the R-square value of all M-REITs' is relatively lower, with an average value of 0.0454 compared to S-REITs', with an average value of 0.3622 , which is about eight times higher than M-REITs". This can be interpreted that the fund of S-REITs' is highly diversified. In average, the total risks of both S-REITs' and M-REITs' are strongly affected by the unsystematic risk factors rather than systematic risk factors.

However, the average diversification measure of M-REITs' is higher than S-REITs', which valued approximately 0.95464 and 0.63781 respectively. For M-REITs', the highest and the lowest diversification value ranged from 0.99942 (Al-'Aqar Healthcare REIT) and 0.87968 (Tower Real Estate Investment Trust). In contrast, the highest and the lowest diversification measure of S-REITs' ranged from 0.95365 and 0.41614 , which are Cache Logistics Trust and Suntec Real Estate Investment Trust respectively. This implies that the M-REITs' has greater opportunities for diversification. 
Table 3 and Table 4 represents the Sharpe, Treynor and Jensen's Alpha ratio analysis of M-REITs' and S-REITs' respectively.

Insert table 3 and table 4

M-REITs' have higher average Sharpe ratio compared to S-REITs'. By comparing the Sharpe Ratio analysis for both M-REITs' and S-REITs', it is observed that the overall performance of M-REITs' is more attractive as most of the MREITs' recorded a positive Sharpe ratio value. Sunway Real Estate Investment Trust generated the highest value of Sharpe ratio among all the M-REITs' with the value of 6.28789. On the other hand, the M-REIT which recorded the lowest value is Tower Real Estate Investment with 0.57972. In contrast, the overall risk-adjusted performance of SREITs' is not as attractive as M-REITs". The overall Sharpe ratio of S-REITs' is considered extremely low when compared to M-REITs', with 8 out of the 26 S-REITs' generating negative values of Sharpe ratio (i.e. AIMS AMP Capital Industrial Reit, Cache Logistics Trust, Cambridge Industrial Trust, OUE Com, Sabana Shariah Compliant REIT, Soilbuild, SPH REIT, and Lippo Malls Indonesia Retail Trust). These REITs with a negative Sharpe ratio value implied that the average portfolio return underperformed against the investments which generates risk free rate of return.

The risk-adjusted performance for both M-REITs' and S-REITs' based on average Treynor Ratio also observed that M-REITS' compared to S-REITs' is almost similar to Sharpe Ratio, while the risk-adjusted performance of M-REITs' is much better than S-REITs'. None of the M-REITs' recorded a negative Treynor ratio value

This implies that the M-REITs' are generating excess return against the investments in risk free rate of return. On the other hand, the risk-adjusted performances of S-REITs' underperformed against the market benchmark. From the table, First Real Estate Investment Trust has the highest value of Treynor Ratio with 0.23326 , followed by Fortune REIT and Parkway Life REIT with the value of 0.15286 and 0.15795 respectively. The S-REIT with lowest value is AIMS AMP Capital Industrial Reit of -1.95153.

On the basis of the Jensen's Alpha analysis of M-REITs' and S-REITs' respectively, M-REITs' recorded a higher Jensen's Alpha average value as compared to S-REITs'. All the 16 M-REITs' outperformed the benchmark of FBM Kuala Lumpur Property Index as all the M-REITs' generated a positive Jensen's Alpha value. Pavilion REIT recorded the highest Jensen's Alpha value of 0.13706. It was followed by Axis REIT and Sunway REIT with the value of 0.12421 and 0.12309 respectively. Compared to M-REITs', some S-REITs' recorded negative Jensen's Alpha values, which included AIMS AMP Capital Industrial Reit, Cache Logistics Trust, Cambridge Industrial Trust, OUE Com, Sabana Shariah Compliant REIT, Soilbuild, and Starhill Global REIT. These REITs underperformed against the benchmark of market portfolio.

Based on the findings above, the decision rule is not to reject null hypotheses (H0) and reject alternative hypotheses (H1). (Table 5). Firstly, M-REITs' have lower beta compared to S-REITs'. Results of Sharpe ratio, Treynor ratio and Jensen's Alpha proved that M-REITs' have better risk-adjusted performance than S-REITs'. M-REITs' have higher average of Sharpe ratio, Treynor ratio and Jensen's Alpha compared to S-REITs'.

\section{CONCLUSION AND IMPLICATIONS}

This study conducted was to compare and analyse the overall performance among the M-REITs' and S-REITs' by applying the risk-adjusted measures of Sharpe ratio, Treynor ratio and Jensen's Alpha. The research also compared the risk diversification effectiveness of M-REITs' compared to S-REITs' using diversification measures. The study period for M-REITs' is from 2007 to 2016, while the study period for S-REITs' is from 2002 to 2016. The results show that on average, the returns from M-REITs' performed better than S-REITs' in terms of Sharpe ratio, Treynor ratio, and Jensen's Alpha as most of M-REITs" achieved positive values while some S-REITs' obtained negative values. This indicates that M-REITs' generate better returns than investments with risk free rate of returns in Malaysia as compared to S-REITs' in Singapore.

According to Sharpe ratio, all M-REITs" achieved a positive Sharpe ratio value. However, 8 out of 26 S-REITs" recorded a negative Sharpe ratio value and the results indicated that S-REITs' gained lesser returns as compared to risk free rate of returns. In terms of Treynor ratio, all M-REITs' obtained a positive Treynor ratio values. However nine out of twenty-six S-REITs" have negative values indicating that S-REITs" do not perform up to a risk free rate 
level. The positive ratios of M-REITs' showed that it has gained more return compared to risk free rate. Based on Jensen Alpha, all M-REITs' have a common result, - positive Jensen Alpha values. This result showed that M-REITs" outperformed the FBM Kuala Lumpur Property Index. However, 7 out of 26 S-REITs" achieved negative Jensen Alpha value, indicating an under-performance in terms of returns as compared to ST Real Estate Investment Trust Index. The total risk of S-REITs' is higher than M-REITs'. The Beta values for both M-REITs' and S-REITs' are less than one, implying that both REITs are less risky than the market. M-REITs' have lower R-Squared values than SREITs', which suggests that M-REITs' are poorly diversified than S-REITs' and therefore, M-REITs' have more diversification opportunities. M-REITs' have higher diversification measures as compared to S-REITs', and this implies that M-REITs' may have better risk diversification benefits.

The findings suggested that low-risk appetite investors could consider investing in M-REITs' because they carry lower risk as compared to S-REITs' and they outperformed the Malaysia T-Bills (investments in risk free rate of returns) and FBM Kuala Lumpur Property Index.

In conclusion, investors should plan their own strategy throughout their investment plans along with the essential technical analysis of the market cycles. Following by some of the major swings and volatility in the market as well as the economy, the REITs offer certain protection against capital loss, as well as to safeguard the investment values among the investors. Findings of this research may assist both investors as well as readers to understand the total risk involved take into account M-REITs' and S-REITs' by providing useful quantitative experimental valuation of the current and past performance of Malaysia Real Estate Investment Trusts and Singapore Real Estate Investment Trusts to assist investors choose the better investment tool. Moreover, quality of corporate management, trust management, asset quality and also the growth strategy of each REIT has to be evaluated by the investors in order to make a precise investment decision.

\section{REFERENCES}

1. Hamzah, A. H. \& Rozali, M. B. (2010). Empirical Investigation on the Performance of the Malaysian Real Estate Investment Trusts in Pre Crisis, During Crisis and Post Crisis Period. International Journal of Economics and Finance, 2(2), pp. 62-69.

2. Hartzell, J.C, Sun, L. \& Titman, S. (2006). The Effect of Corporate Governance on Investment: Evidence from Real Estate Investment Trusts. Real Estate Economics 34:343-376.

3. Jensen, M.C. (1968). The Performance of Mutual Funds in the Period 1945-1946. Journal of Finance, 23, 1968, pp. $389-416$.

4. Liow, K. H. (2001). The long-term investment performance of Singapore real estate and property stocks. Journal of Property Investment \& Finance, 19(2). 156-174.

5. Low, S.W. \& Johari, A. (2014). Risk-Adjusted Performance of Malaysian Real Estate Investment Trust Funds. Jurnal Pengurusan, 41: 3-11

6. Markowitz, H. (1952). Portfolio Selection. The Journal of Finance, 7(1), 77-91

7. Ng, C.Y., Lim, B.K., Lau, T.C., \& Yuen, M.K. (2016). A Study on the Performance and Risk Diversification Benefits of Real Estate Investment Trusts in Malaysia. Unpublished doctoral thesis, Universiti Tunku Abdul Rahman \& Universiti Technologi Malaysia.

8. Sharpe, W.F. (1966). Mutual Fund Performance. Journal of Business. 39(S1): 119-138

9. Sharpe, W. F., Alexander, G. J., \& Bailey, J. V. (1999). Investments, (6th ed.). Prentice Hall, New Jersey

10. Smith, K.V. \& Shulman, D (1976). Institution beware: The performance of equity Real Estate Investment Trust. Financial Analyst Journal, 32: 61-66.

11. Treynor, J.L. (1965). How to Rate management of Investment Funds. Harvard Business Review 43, pp. 63-75 
Table 1. Risk Features of M-REITs

\begin{tabular}{|c|c|c|c|c|c|c|c|}
\hline No & REITs & Beta $(\beta)$ & $\mathrm{R}$-square & Total risk & Systematic risk & Unsystematic risk & $\begin{array}{l}\text { Diversification } \\
\text { measure }\end{array}$ \\
\hline 1 & Amanah Harta Tanah PNB & 0.0424 & 0.0025 & 2.8123 & 0.0072 & 2.8050 & 0.9974 \\
\hline 2 & Al-'Aqar Healthcare REIT & 0.0257 & 0.0005 & 6.8170 & 0.0039 & 6.8131 & 0.9994 \\
\hline 3 & $\begin{array}{l}\text { AmFirst Real Estate Investment } \\
\text { Trust }\end{array}$ & 0.2255 & 0.1084 & 2.8025 & 0.3038 & 2.4987 & 0.8915 \\
\hline 4 & $\begin{array}{ll}\text { AmanahRaya } & \text { Real Estate } \\
\text { Investment Trust } & \end{array}$ & 0.1060 & 0.0102 & 6.5429 & 0.0670 & 6.4758 & 0.9897 \\
\hline 5 & $\begin{array}{l}\text { Atrium Real Estate Investment } \\
\text { Trust }\end{array}$ & 0.1997 & 0.0810 & 2.9432 & 0.2384 & 2.7047 & 0.9189 \\
\hline 6 & Axis Real Estate Investment Trust & 0.2180 & 0.0462 & 6.1501 & 0.2843 & 5.8658 & 0.9537 \\
\hline 7 & CapitaLand Malaysia Mall Trust & 0.1691 & 0.0187 & 6.1109 & 0.1145 & 5.9963 & 0.9812 \\
\hline 8 & $\begin{array}{l}\text { Hektar Real Estate Investment } \\
\text { Trust }\end{array}$ & 0.0897 & 0.0073 & 6.5811 & 0.0480 & 6.5331 & 0.9926 \\
\hline 9 & IGB Real Estate Investment Trust & 0.1504 & 0.0221 & 3.5715 & 0.0789 & 3.4925 & 0.9778 \\
\hline 10 & $\begin{array}{llll}\text { KLCC } & \text { Real Estate Investment } \\
\text { Trust } & & & \end{array}$ & 0.3490 & 0.0917 & 7.9301 & 0.7276 & 7.2025 & 0.9082 \\
\hline 11 & MRCB-Quill REIT & 0.2166 & 0.0633 & 2.9644 & 0.1876 & 2.7768 & 0.9366 \\
\hline 12 & $\begin{array}{l}\text { Sunway Real Estate Investment } \\
\text { Trust }\end{array}$ & 0.2372 & 0.0511 & 4.4010 & 0.2252 & 4.1757 & 0.9488 \\
\hline 13 & $\begin{array}{l}\text { Pavilion Real Estate Investment } \\
\text { Trust }\end{array}$ & 0.1699 & 0.0153 & 6.1667 & 0.0944 & 6.0722 & 0.9846 \\
\hline 14 & $\begin{array}{l}\text { Tower Real Estate Investment } \\
\text { Trust }\end{array}$ & 0.2578 & 0.1203 & 3.3016 & 0.3972 & 2.9044 & 0.8796 \\
\hline 15 & UOA Real Estate Investment & 0.1635 & 0.0358 & 4.4412 & 0.1592 & 4.2820 & 0.9641 \\
\hline \multirow[t]{2}{*}{16} & YTL Hospitality REIT & 0.1476 & 0.0507 & 2.5642 & 0.1302 & 2.4340 & 0.9492 \\
\hline & Average & 0.1730 & 0.0453 & 4.7563 & 0.1917 & 4.5645 & 0.9546 \\
\hline
\end{tabular}

Table 2. Risk Features of S-REITs'

\begin{tabular}{|c|c|c|c|c|c|c|c|}
\hline No & REITs & Beta $(\beta)$ & R-square & Total risk & Systematic risk & Unsystematic risk & $\begin{array}{l}\text { Diversification } \\
\text { measure }\end{array}$ \\
\hline 1 & AIMS AMP Capital Industrial Reit & 0.6802 & 0.2782 & 17.2541 & 4.8016 & 12.4524 & 0.7217 \\
\hline 2 & $\begin{array}{l}\text { Ascendas Real Estate Investment } \\
\text { Trust }\end{array}$ & 0.9659 & 0.5407 & 15.3186 & 8.2840 & 7.0346 & 0.4592 \\
\hline 3 & Ascott Residence Trust & 0.8038 & 0.3628 & 18.5432 & 6.7277 & 11.8155 & 0.6371 \\
\hline 4 & Cache Logistics Trust & 0.7020 & 0.0463 & 3.4598 & 0.1603 & 3.2994 & 0.9536 \\
\hline 5 & Cambridge Industrial Trust & 0.7334 & 0.3515 & 16.3862 & 5.7606 & 10.6255 & 0.6484 \\
\hline 6 & CapitaLand Commercial Trust & 1.1228 & 0.5679 & 21.2105 & 12.0473 & 9.1632 & 0.4320 \\
\hline 7 & CapitaLand Mall Trust & 1.3298 & 0.5549 & 27.6982 & 15.3716 & 12.3265 & 0.4450 \\
\hline 8 & First Real Estate Investment Trust & 0.3796 & 0.2111 & 7.4515 & 1.5730 & 5.8784 & 0.7889 \\
\hline 9 & $\begin{array}{l}\text { Fortune Real Estate Investment } \\
\text { Trust }\end{array}$ & 0.6549 & 0.1529 & 11.7165 & 1.7923 & 9.9242 & 0.8470 \\
\hline 10 & Frasers Centrepoint Trust & 0.6549 & 0.3568 & 12.8299 & 4.5779 & 8.2520 & 0.6431 \\
\hline 11 & Frasers Commercial Trust & 1.1665 & 0.4858 & 6.8715 & 3.3385 & 3.5330 & 0.5141 \\
\hline 12 & Frasers Logistics \& Industrial Trust & 1.2133 & 0.5447 & 7.5568 & 4.1165 & 3.4403 & 0.4552 \\
\hline 13 & MapleTree Log Trust & 0.6715 & 0.3268 & 14.0364 & 4.5874 & 9.4490 & 0.6731 \\
\hline 14 & OUE Com & 0.8728 & 0.3541 & 4.7127 & 1.6690 & 3.0437 & 0.6458 \\
\hline 15 & Parkway Life Reit & 0.4489 & 0.2068 & 10.2215 & 2.1140 & 8.1074 & 0.7931 \\
\hline 16 & Sabana Shariah Compliant REIT & 0.6018 & 0.2076 & 4.5579 & 0.9462 & 3.6116 & 0.7924 \\
\hline 17 & Soilbuild & 0.7339 & 0.3177 & 3.6440 & 1.1578 & 2.4862 & 0.6822 \\
\hline 18 & SPH REIT & 0.5157 & 0.2436 & 2.3657 & 0.5763 & 1.7893 & 0.7563 \\
\hline 19 & $\begin{array}{l}\text { Suntec Real Estate Investment } \\
\text { Trust }\end{array}$ & 0.9095 & 0.5838 & 13.9790 & 8.1618 & 5.8172 & 0.4161 \\
\hline 20 & Starhill Global REIT & 0.6005 & 0.3265 & 10.9263 & 3.5675 & 7.3588 & 0.6734 \\
\hline 21 & Mapletree Industrial Trust & 0.8005 & 0.3201 & 5.2172 & 1.6703 & 3.5468 & 0.6798 \\
\hline 22 & $\begin{array}{l}\text { Mapletree Greater China } \\
\text { Commercial Trust }\end{array}$ & 1.1047 & 0.4494 & 7.3187 & 3.2895 & 4.0292 & 0.5505 \\
\hline 23 & Mapletree Commercial Trust & 1.0467 & 0.5451 & 5.2830 & 2.8799 & 2.4031 & 0.4548 \\
\hline
\end{tabular}




\begin{tabular}{|l|l|l|l|l|l|l|l|}
\hline 24 & Lippo Malls Indonesia Retail Trust & 0.8677 & 0.2621 & 30.0787 & 7.8863 & 22.1923 & 0.7378 \\
\hline 25 & Keppel DC REIT & 0.8451 & 0.4389 & 4.6081 & 2.0225 & 2.5856 & 0.5611 \\
\hline 26 & Keppel REIT & 0.7869 & 0.3797 & 17.2616 & 6.5558 & 10.7057 & 0.6202 \\
\hline & Average & $\mathbf{0 . 8 1 5 9}$ & $\mathbf{0 . 3 6 2 1}$ & $\mathbf{1 1 . 5 5 8 0}$ & $\mathbf{4 . 4 4 7 5}$ & $\mathbf{7 . 1 1 0 4}$ & $\mathbf{0 . 6 3 7 8}$ \\
\hline
\end{tabular}

Table 3. Sharpe, Treynor and Jensen's Alpha Ratio of M-REITs'

\begin{tabular}{|l|l|l|l|l|}
\hline No. & M-REITs' & Sharpe Ratio & Treynor Ratio & Jensen's Alpha \\
\hline 1 & Amanah Harta Tanah PNB & 1.47960 & 0.58508 & 0.02364 \\
\hline 2 & Al-'Aqar Healthcare REIT & 3.75937 & 3.81447 & 0.09826 \\
\hline 3 & AmFirst Real Estate Investment Trust & 1.38166 & 0.10254 & 0.02456 \\
\hline 4 & AmanahRaya Real Estate Investment Trust & 1.28532 & 0.31007 & 0.03353 \\
\hline 5 & Atrium Real Estate Investment Trust & 2.20357 & 0.18923 & 0.03864 \\
\hline 6 & Axis Real Estate Investment Trust & 4.97187 & 0.56548 & 0.12421 \\
\hline 7 & CapitaLand Malaysia Mall Trust & 4.44836 & 0.65030 & 0.10413 \\
\hline 8 & Hektar Real Estate Investment Trust & 1.56344 & 0.44692 & 0.04068 \\
\hline 9 & IGB Real Estate Investment Trust & 3.24677 & 0.40774 & 0.06094 \\
\hline 10 & KLCC Real Estate Investment Trust & 3.44347 & 0.27779 & 0.09919 \\
\hline 11 & MRCB-Quill REIT & 4.35032 & 0.34578 & 0.06857 \\
\hline 12 & Sunway Real Estate Investment Trust & 6.28789 & 0.55604 & 0.12309 \\
\hline 13 & Pavilion Real Estate Investment Trust & 5.62628 & 0.82211 & 0.13706 \\
\hline 14 & Tower Real Estate Investment Trust & 0.57972 & 0.04085 & 0.01217 \\
\hline 15 & Uoa Real Estate Investment & 2.55295 & 0.32904 & 0.05387 \\
\hline 16 & YTL Hospitality REIT & 2.38897 & 0.25904 & 0.03919 \\
\hline Average of M-REITs' & $\mathbf{3 . 0 9 8 1}$ & $\mathbf{0 . 6 0 6 4}$ & $\mathbf{0 . 0 6 7 6}$ \\
\hline
\end{tabular}

Table 4. Sharpe, Treynor and Jensen's Alpha Ratio of of S-REITs'

\begin{tabular}{|l|l|l|l|l|}
\hline No. & S-REITs' & Sharpe Ratio & Treynor Ratio & Jensen's Alpha \\
\hline 1 & AIMS AMP Capital Industrial Reit & -1.95153 & -1.95153 & -0.06142 \\
\hline 2 & Ascendas Real Estate Investment Trust & 2.20678 & 0.08942 & 0.03493 \\
\hline 3 & Ascott Residence Trust & 0.67692 & 0.03626 & 0.02627 \\
\hline 4 & Cache Logistics Trust & -1.31877 & -0.03494 & -0.02888 \\
\hline 6 & Cambridge IndustrialTrust & -0.04399 & -0.00243 & -0.01069 \\
\hline 7 & CapitaLand Commercial Trust & 1.67611 & 0.06875 & 0.03578 \\
\hline 8 & CapitaLand Mall Trust & 1.97975 & 0.07835 & 0.03211 \\
\hline 9 & First Real Estate Investment Trust & 3.24417 & 0.23326 & 0.10140 \\
\hline 10 & Fortune Real Estate Investment Trust & 2.02931 & 0.15862 & 0.05207 \\
\hline 11 & Frasers Centrepoint Trust & 1.96309 & 0.10737 & 0.06221 \\
\hline 12 & Frasers Commercial Trust & 3.07305 & 0.06906 & 0.07151 \\
\hline 13 & Frasers Logistics \& Industrial Trust) & 0.30182 & 0.00684 & 0.06083 \\
\hline 14 & MapleTree Log Trust & 1.30840 & 0.07300 & 0.04822 \\
\hline 15 & OUE Com & -1.01680 & -0.02529 & -0.00852 \\
\hline 16 & Parkway Life) & 2.21771 & 0.15795 & 0.08094 \\
\hline 17 & Sabana Shariah Compliant REIT & -7.16966 & -0.25432 & -0.14962 \\
\hline 18 & Soilbuild & -3.55834 & -0.09254 & -0.04722 \\
\hline 19 & SPH REIT & -0.16445 & -0.00490 & 0.01841 \\
\hline 20 & Suntec Real Estate Investment Trust & 1.50973 & 0.06206 & 0.03487 \\
\hline 21 & Starhill Global REIT & 0.11764 & 0.00647 & -0.00026 \\
\hline 22 & Mapletree Industrial Trust & 3.63315 & 0.10366 & 0.09077 \\
\hline 23 & Mapletree Greater China Commercial Trust) & 0.01424 & -0.01886 & 0.06095 \\
\hline 24 & Mapletree Commercial Trust & 3.32237 & 0.07295 & 0.08155 \\
\hline 25 & Lippo Malls Indonesia Retail Trust & -0.05896 & -0.00373 & 0.01088 \\
\hline 26 & Keppel DC REIT & 5.33442 & 0.13549 & 0.16377 \\
\hline Average of S-REITs' & 0.30073 & 0.01588 & 0.01048 \\
\hline
\end{tabular}

Table 5. Major Findings on Hypotheses Testing

\begin{tabular}{|c|c|c|c|}
\hline No. & Hypotheses & Findings & Conclusion \\
\hline \multirow[t]{2}{*}{1} & $\begin{array}{l}\mathrm{H}_{\mathrm{o}}: \text { M-REITs" } \beta>\text { S-REITs" } \beta \text { (M-REITs' have higher } \\
\text { Beta [market risk] compared to S-REITs') }\end{array}$ & \multirow{2}{*}{$\begin{array}{l}\text { M-REITs" Beta (0.17305) } \\
< \\
\text { S-REITs" Beta }(0.81595)\end{array}$} & Reject $\mathrm{H}_{\mathrm{o}}$ \\
\hline & $\begin{array}{l}\mathrm{H}_{1}: \text { M-REITs" } \beta<\text { S-REITs" } \beta \text { (M-REITs' have lower Beta } \\
\text { [market risk] compared to S-REITs') }\end{array}$ & & Do not reject $\mathrm{H}_{1}$ \\
\hline 2 & $\begin{array}{l}\mathrm{H}_{\mathrm{o}}: \text { M-REITs" } \mathrm{Si}<\mathrm{S} \text {-REITs" Si (M-REITs' have lower } \\
\text { Sharpe ratio compared to S-REITs') }\end{array}$ & $\begin{array}{l}\text { M-REITs" Sharpe Ratio (3.0981) } \\
>\end{array}$ & Reject $\mathbf{H}_{\mathrm{o}}$ \\
\hline
\end{tabular}




\begin{tabular}{|c|c|c|c|}
\hline & $\begin{array}{l}\mathrm{H}_{1}: \text { M-REITs" } \mathrm{Si}>\mathrm{S} \text {-REITs" Si (M-REITs' have higher } \\
\text { Sharpe ratio compared to S-REITs') }\end{array}$ & S-REITs" Sharpe Ratio (0.7549) & Do not reject $\mathrm{H}_{1}$ \\
\hline \multirow[t]{2}{*}{3} & $\begin{array}{l}\mathrm{H}_{\mathrm{o}} \text { : M-REITs" Ti }<\text { S-REITs" Ti (M-REITs' have lower } \\
\text { Treynor ratio compared to S-REITs') }\end{array}$ & \multirow{2}{*}{$\begin{array}{l}\text { M-REITs" Treynor Ratio }(0.6064) \\
> \\
\text { S-REITs" Treynor Ratio }(-0.0351)\end{array}$} & Reject $\mathbf{H}_{\mathrm{o}}$ \\
\hline & $\begin{array}{l}\mathrm{H}_{1}: \text { M-REITs" Ti > S-REITs" Ti (M-REITs' have higher } \\
\text { Treynor ratio compared to S-REITs') }\end{array}$ & & Do not reject $\mathrm{H}_{1}$ \\
\hline \multirow[t]{2}{*}{4} & $\begin{array}{l}\mathrm{H}_{\mathrm{o}} \text { : M-REITs" } \alpha \mathrm{i}<\mathrm{S} \text {-REITs" } \alpha \mathrm{i}(\mathrm{M}-\mathrm{REITs} \text { ' have lower } \\
\text { Jensen's Alpha compared to S-REITs') }\end{array}$ & \multirow{2}{*}{$\begin{array}{l}\text { M-REITs" Jensen’s Alpha (0.0676) } \\
\text { > } \\
\text { S-REIT’s Jensen's Alpha (0.029667) }\end{array}$} & Reject $\mathbf{H}_{\mathbf{o}}$ \\
\hline & $\begin{array}{l}\text { H }{ }_{1}: \text { M-REITs" } \alpha \mathrm{i}>\mathrm{S} \text {-REITs" } \alpha \mathrm{i}(\mathrm{M}-\mathrm{REITs} \text { ' have higher } \\
\text { Jensen's Alpha compared to S-REITs') }\end{array}$ & & Do not reject $\mathrm{H}_{1}$ \\
\hline \multirow[t]{2}{*}{5} & $\begin{array}{l}\mathrm{H}_{\mathrm{o}}: \text { M-REITs" } \mathrm{Rd}<\mathrm{S} \text {-REITs" Rd (M-REITs' have lower } \\
\text { risk diversification benefits compared to S-REITs') }\end{array}$ & $\begin{array}{l}\text { M-REITs" Diversifiability } \quad \text { Measure } \\
(0.95464)\end{array}$ & Reject $\mathbf{H}_{\mathbf{o}}$ \\
\hline & $\begin{array}{l}\mathrm{H}_{1}: \text { M-REITs" Rd > S-REITs" Rd (M-REITs' have higher } \\
\text { risk diversification benefits compared to S-REITs') }\end{array}$ & $\begin{array}{l}> \\
\text { S-REITs" } \quad \text { Diversifiability } \quad \text { Measure } \\
(0.63781)\end{array}$ & Do not reject $\mathrm{H}_{1}$ \\
\hline
\end{tabular}

